\title{
Financial Exclusion of Small and Medium Enterprise and Poverty Alleviation: Nigeria Experience
}

\author{
Kanu Clementina \\ Accountancy Department, \\ Federal University, Ndufu-Alike, Abakaliki, \\ Ebonyi State, Nigeria. \\ Chukwu Oyims Kelvin Egwu \\ Accountancy Department, \\ Federal University, Ndufu-Alike, Abakaliki, \\ Ebonyi State, Nigeria.
}

\begin{abstract}
The role of banks especially sourcing from the surplus units and supplying to the deficit units of the economy (which is no other than the poor that have been denied access to the financial services by the banks) is mostly needed for the alleviation of poverty in Nigeria . Banks, instead of supplying to the deficit units, ended up in supplying funds to the surplus unit believing that the poor as well as rural dwellers cannot repay if loans are granted to them. Robust economic growth cannot be achieved without putting in place well focused programmes to reduce poverty through empowering the people by increasing their access to factors of production, especially credit (CBN, 2005). This paper sets out to assess how poverty can be alleviated through banks' roles and the level of poverty experienced by people. Based on our research findings we posit that allowing access to financial services at a reduced interest rate will enhance in poverty reduction in the country and make most active poor selfreliance. Again, due to the large population of the country and the state of the Nation's economy, the role of the financial institutions alone would not be sufficient in alleviation poverty in the country. Therefore, provision and maintenance of social amenities by government for populace in the country is required. The implication of this study is that government should design a policy for banks that focus on including the poor on the financial services instead of multiplication of programmes to reach the poor which have never been successful.
\end{abstract}

Key words: Banks' Role, financial services, Poverty alleviation, Poor and Rural populace, Small and Medium Enterprises, economy and development.

\section{INTRODUCTION}

More than half of Nigerians eat twice daily if not once because of the economic situation in the country. Lager numbers of people continue to live in poverty and more dwell in abject poverty. Poverty is characterized by the absence of the basic needs of existence -food, shelter and clothing. It often finds expression in voicelessness and powerlessness- not having a say in issues that concern the oneself; not being represented adequately and knowing there is nothing you can do about it (Mini.C.C 2007) 
More so, UNDP (2010) ranked Nigeria as 142nd in a sample of 169th poorest countries in the world. Unsurprisingly, the poor are disproportionately located in rural areas, primarily engaged in agricultural and associated activities; some are owners of SMEs and are mostly women and children than adult males (Todaro, 2000). The poor commenced their businesses in small scale and that was how many SMEs were started yet they been deprived of formal financial services.

The roles of banks include; intermediation- sourcing fund from surplus units and supply to deficit units and granting of credits to people. The issue of financing active poor in the rural areas through formal financial institutions is difficult in Nigeria. Kanu .C. (2014) maintain that people are created equal and should be treated fairly. The poor, especially poor women are business worthy as any other person and they deserve to have access to financial services. The inability of commercial banks to render their services religiously and to the benefit of the society at large made government to initiate another programmes to reach the poor. The question is whether the programmes initiated by government have breached the gap. The role of intermediation - from surplus to deficit units and granting of credit make no distinction between the poor and rich clients of the banks.

After all, the deficit units should be no where other than in the hands of the poor where the funds are lacking. According to National Financial Inclusion, in the provision of financial services, Nigeria lags behind many African countries. In 2010, 36\% of adults - roughly 31 million out of an adult population of 85 million - were served by formal financial services. This figure compares to $68 \%$ in South Africa and $41 \%$ in Kenya

Several efforts made by Nigerian government to raise the standard of living of People and to turn out more entrepreneurs not job seekers include the following:

- Directorate of food, Roads and Rural Infrastructure (DFRRI)

- Better Life/Family Support Programme

- The Family Economic advanced programme

- Peoples Bank

- Community banks

- Microfinance Bank.

The aim of government for establishing these banks is to make available small credit with minimum interest to the poor without insisting on asset based collateral and those financial services will be easily accessible even to the people at the grass root. It is good to note that none of these programmes succeeded in achieving its objective due to poor implementation and host of other factors. However, amidst all these efforts, the poor ones are still becoming poorer. The objectives of this study are to evaluate the factors that enhance the exclusion of small and medium enterprise from financial services and to investigate the level of availability and accessibility of social amenities to the poor in the urban and rural areas. The paper is divided into five sections; following this introductory part, is literature review on the poverty alleviation and role of banks in the economy, section three deals on the SMEs and financial services delivery, section four: methodology and summary of the findings, concluding remarks in section five.

\section{REVIEW OF LITERATURE}

The issue of poverty alleviation is the impact of resources allocation on the lives of poor people. 
Narsir (2002) defined poverty as a concept that entails socio-economic and political deprivation which may affect individuals' households, or communities and which may result in lack of access to the basic necessities of life. Poverty is not having a job, is fear for the future. Poverty is losing a child to illness as a result of malnutrition.

Economic development is about enhancing the productive capacity of an economy by using available resources to reduce risks, remove impediments and alleviate poverty. Mini C.C (2007), maintain that due to fragile resource base of the country, slight distortions in the allocation of resources enormously aggravate the already existing poverty. Where there is equal distribution of resources all of which gear up to raise the standard of living of the rural population and reduce poverty alleviation

Most nations concentrate their development in the urban area but when a nation extends its development to the rural areas poverty is alleviated and economy improved. Rural dwellers produced the highest percentage of nation's food with no significant development in the areas, no good roads, electricity, and good water supply, education, health services no banks among things. The banking sector has not done much to enhance eonomicc development in the country by not extending financial services to the poor and rural dweller. Many researchers conclude that in most developing countries, the formal financial system reaches to only top 25 per cent of the economically active population. This leaves 75 per cent without access to financial services apart from those provided by money-lenders and family. Savings have continued to grow at a very low rate, particularly in the rural areas of Nigeria. Most poor people keep their resources in kind or simply under their pillows because of inadequate savings opportunities and products. Such methods of keeping savings are risky, yield no returns, and reduce the aggregate volume of resources that could be mobilized and channeled to deficit areas of the economy. (Kanu, 2014).

Improving households' access to financial services will also help to reduce poverty and improve income equality while financial exclusion can retard economic growth and increase poverty and inequality (Butler and Cornaggia, 2008). Robust economic growth cannot be achieved without putting in place well focused programmes to reduce poverty through empowering the people by increasing their access to factors of production, especially credit (CBN, 2005).

Adeyemi (2008) observes that across the globe, governments of various developing countries have sought to provide finance to the poor through the creation of agricultural development banks, special lending schemes, and the support of the growth of cooperatives and other selfhelp groups (SHGs). The aim is to reduce the level of poverty in the lives of people. The organization whose responsibility it is to grant this credit does not have active poor as one of their target groups.

Ehigiamusoe (2008) maintain that the improving condition of living in Bangladesh is a good example of how to develop with small loans. Again, the South East Asian nation was in mid1970s branded a 'basket case' by Henry Kissinger (the US Secretary of State at the time) on accounts of the nation's hopeless development prospects. In the of Nigeria, banking sector concentrate in granting loans to the rich with the aim that they are only people that can repay; at the end of the day, many will turn out to be bad loans even the loans borrowed by the government. The percentage of people that have no access to banking services is above average. Imagine where these people are opportune to enjoy such services, many lives could have been touched; hence imp roved standard of living. After all the poor know what to do but obtaining the finance to achieve their aim is the major problem. 
Stuart Rutherford in Bangladesh observed that even where microfinance institutions moved into underserved markets, they commanded a small share of business compared to other informal services. His work has revealed the poor as discerning consumers, who use a variety of informal products to meet complex financial needs. Some practitioners stress the need to replace informal services with formal inclusion that offers reliability, less risk of loss, and better privacy.

Adeyemi (2008) however, documents that despite decades of public provision and direction of provision of microcredit, policy reorientation, and the entry of new players, the supply of microfinance in Nigeria is still inadequate in relation to demand. Above all, microfinance banks in order countries have donors, as a result, their cost of operations are much lesser than that of Nigeria. It may not be possible for microfinance banks that are struggling to survive to sustain businesses in the country or alleviate the poverty of the people in the grass root.

Although, Odoko (2008) argue that finance alone is not enough. Other complementary strategies must be adopted if we are to realize the goal of poverty reduction in Nigeria. Some of these factors are reviewed as the type and size of the project, the credit history of the borrower, the prevailing economic conditions, and the level of competition in the industry. Hence Okpara (2010) maintain that these factors are of secondary concern. It is when finance sources are established for purpose of the poor that one can talk of appraisal and disbursement technique. The researcher strongly believe that if banks can extend their services to the poor who are the initiator of small and medium enterprises in various rural areas of the country, the level of poverty should be reduced. After all the poor know what to do but securing funds to actualize their vision turns to a nightmare fantasy.(Okpara, 2010).

Nigerian government has initiated many programmes before establishing microfinance banks, aimed at alleviating poverty but none was free from inefficiency, high transaction cost, inconsistencies and lack of sincerity, focus and commitment in their implementation, The inability of the formal financial institutions to provide financial services to the poor, coupled with non sustainability of government programme makes it difficult to stem the tide of poverty in the country. Many researchers maintained that sustained economic growth can contribute significantly to poverty reduction. Indeed, countries that have enjoyed economic growth for long periods of time have witnessed marked declines in poverty incidence; an economic and financial crisis could frustrate such development.

\section{Small and Medium Enterprises and Nigerian Economy}

Earlier before now small and medium enterprise have been taken to be instrumental for economic growth and national development both in developed and developing countries which Nigeria is one of them through generation of employment. (Kanu, Onuoha \& Isu, 2014)

Small and Medium Enterprises are seen today as the backbone of every economy throughout the world, (Ojeka and Dickson, 2011). SMEs are significant in the country's economy. SMEs are defined using a certain characteristics, but differs with economies. Some of these include: ownership structure, size, turnover, number of employees, total assets and capital base. These kinds of companies exist all over the continent and in all sectors in Nigeria. SMEs in Nigeria consist of the private sectors, professionals groups and associations. They drive the economy of Nigeria. Imagine where these were better funded and organized, SMEs could have contributed more to the economy. 
Various studies conducted by academia, professional and governmental agencies confirm the fact that SMEs are the engine of economic growth and development. While the actual figures vary from country to country, it is believed that on average SMEs (both from the formal and informal sectors) account for between $70 \%$ and $90 \%$ of employment and bb70\% of National output.

Agric. Sector accounts for $40 \%-45 \%$ of GDP in Nigeria and $70 \%$ of employment. Over $80 \%$ of the Agriculture sector is either subsistence farming or SMEs Agro-allied business if properly setup, managed and funded, SMEs provided the much needed employment to a large section of the economy in Nigeria. SMEs provide household incomes which drives consumption and which in turn drives economic growth. Some researchers maintain that in the central and eastern Europe SMEs are perceived as the most vibrant and healthier sector of the economies in comparison with the larger entities

Also, good number of SMEs grow over the years to become huge corporations. All companies essentially start small as SMEs but some later grow and become the big corporations we love to hear and talk about example, Tantalizers, ABC Transport, Computer Warehouse Group, Ibeto Group of Companies.

Unfortunately, a large proportions of SME startup but never make it off their business plan or past their first year of existence.

The financial lives of the poor are unpredictable, they have low and UN steady income, some days they could get more while other days they would go without any income.

The poor households are lack of financial tool that could help them manage their resources better as a way to get their lives out of poverty.

For individuals who are engaged in activities like peasant farming, which are seasonal, their income could vary even more. Some researchers observed that the nature and flow of income to the poor members of society, their level of uncertainty is high. This translates to them living less healthy lives, staying in less secure places and facing income volatility associated with the market supply and demand dynamics.

Given the low, irregular and unreliable income, tools that facilitate savings, streamlining of cash flows and accumulation for bigger ticket items (lump sums) are of greater value for this class. In their study, Collins et al. (2009) summarised three needs that drive the financial activities of the poor as i) management of basics, which entails managing their cash flow so as to transform the low irregular income into a dependable source for daily living, ii) coping with risk particularly emergencies and iii) raising lump sums whereby they could reliably accumulate meaningful sums of money to buy expensive items or invest.

As earlier stated, most of SMEs in Nigeria do not achieve their fullest potentials of growth and profitability. They are unable to attract any funds to start-off the business. Most SMEs (with the exception of trading companies, government contractors and oil traders) are effectively locked out of traditional sources of financing, and this leads to increased level of poverty in the country. SMEs in Nigeria are faced with numerous challenges as, - Inadequate, inefficient, and at times, non-functional infrastructural facilities,

- inefficient administration

- absence of long-term finance to fund,

- lack of accountability and transparency/ Poor governance 
- incomplete records,

- under project finance for SMEs,

- lack of scientific and technological knowledge,

- Lack of suitable training and leadership development and others.

- Poorly thought-out business ideas / concept

- Lack of separation of "owners pocket from business pocket"

These have hindered them from playing the expected role in Nigeria's economic growth and development. Numerous efforts have been made by government to enhance the survival and the impact of SMEs in Nigerian economic development, but it seems that both environmental and political factors have not give way for the objective to be achieved. Hence, Molokwu B. (2005) said that unfortunately, these SMEs over the years, have been bedeviled by several inhibitions, which tend to make their growth perpetually stunted by infrastructural decay, insecurity of lives and property, multiplicity of taxation, lack of access to good and modern technology, lack of research and development as well as good entrepreneurship, difficulties in building coalitions and business linkages among others. The current problems of hunger poverty and unemployment have undermined the capacity of the economy and small and medium scale enterprises are seen as mechanism for intervention to addressing these long term problem of the economy. Unfortunately, SME have not been able to propel economic growth and development which are quintessence of mitigating the effect of Poverty, hunger, unemployment, and low standard of living. (Abiodu. 2011)

SMEs have played and continue to play significant roles in the growth, development and industrialization of many economies the world over. In the case of Nigeria, SMEs have performed below expectation due to a combination of problems which ranges from attitude and habits of SMEs themselves through environmental related factors, instability of governments and frequent government policy changes and somersaults.

Government is not relenting in their efforts to make SMEs in Nigeria what they should be because of the prospects of SMEs in the country which some authors listed as the crucial role of engine of growth, development and industrialization, employment/ wealth creation and poverty reduction.

Molokwu maintain that SMEs are the largest employer of labor, providing livelihood for over 80 percent of the African work force especially women and the youth and that it is a wellknown fact that the African economy is government-driven while SMEs are the veritable engine of growth in developed economies.

\section{Impact of Credit to Smalland Medium Enterprises}

Loans are essential weapons for fight poverty since most poor cannot afford any amount to expand or even to start a small scale business. However, they know what to do but no money to execute the plan.

The capacity of poor for entrepreneurship would be significantly enhanced through the provision of financial services to enable them engage in economic activities and be more selfreliant, thereby creating employment opportunities rather than turning out more job seekers impacting positively to the economy. Financial access increases incomes through productive investment, helps create employment opportunities, facilitates investments in health and education, and reduces the vulnerability of the poor by helping them to smooth their income patterns over time. 
Lack of rural access to financial services in Nigeria not only retards rural economic growth, but also increases poverty and inequality. Financial access increases incomes through productive investment, helps create employment opportunities, facilitates investments in health and education, and reduces the vulnerability of the poor by helping them to smooth their income patterns over time. While it is well understood in Nigeria that financial exclusion of the rural population from financial services retard economic growth.

\section{Role of Banks in the Nigeria Economy}

The banking system plays the vital role in promoting economic growth and development through their various functions. The role of financial intermediation by banking system is the process by which banks source fund from surplus unit and supply to deficit unit of the economy. Some researchers place the role of financial intermediation at the center of economic development and argued that financial intermediation through the banking system played a pivotal role in economic development by affecting the allocation of savings, thereby improving productivity, technical change and the rate of economic growth. This role also is meant to reduce level of poverty where banks perform it religiously. If the surplus fund will be efficiently allocated to entrepreneurs and active poor in the society to enhance their businesses or even to commence one; standard of living will be improved. This will reduce the level of poverty in the economy where banks will identify the deficit units of the economy. Banks source funds from surplus units and supply to the surplus units in steady of supplying to the deficit units of the economy; thereby leaving the gap uncovered. Banks can only perform their role of intermediation efficiently and effectively by rendering financial services appropriately.

There is general consensus among researchers are expensive for the poor, which keeps them away from the banks because they cannot build dependable credit history, to enable them contribute meaningful to the formal economy.

Formal banking has excluded the small and medium enterprise and could not solve the financial problem of the poor. Nigeria with its expertise experience in the financial sector, banks are only interested in dealing with rich clients and to handle high value transactions, but less keen and slowly in meeting the needs of the poor.

Several developing countries which Nigeria is one of them still struggle with financial sector inefficiencies that affect the economy.

Good number of economists believe that the financial system, with banks as its major component, provide linkages for the different sectors of the economy and encourage high level of specialization, expertise, economies of scale. Some researchers believe that the economic status of any nation depends to a large extend on how effective their banking industries are. This measure is geared towards the use of banking industries in realization and actualization of the development of much neglected rural areas in the country.

Another function of banks is to receive deposits and advance loan to promote business and commerce. The problem is that banks do not extend this service to all the clients that needed it especially the small and medium enterprises. .In most developing countries, formal banks do not consider small and medium enterprises as well as active poor in granting credits. The poor are considered incapable of making savings.

The poor are excluded in the most of the financial services rendered by the formal institutions. According to National Financial inclusion, financial products must be within easy reach for all groups of people and should avoid onerous requirements, such as challenging KYC procedures. 
Formal financial services should be affordable even for low-income groups, particularly when compared to informal services, e.g. esusu or money lenders.

The creation of credit markets in poor countries is a crucial factor for their development. If well implemented, people would be able to sell their products, pay a fair interest rate, and use the extra money to improve their quality of life. With the appropriate help they will become educated and that will allow them to expand their business, to think by themselves and to realize that they have rights. Hence, Kanu.C. (2014) maintain that for human dignity and social justice to flourish, individuals must have hand in their personal development, as opposed to having development "done" to them.

Banks also perform important functions of making payment against cheque, discounting bill of exchange, letter of credit to enhance their business operations. Many researchers in economic growth in Asia maintained that the above activities focus on the role of the financial system in supporting economic growth in Asia, including issues related to financial development, regulation and supervision. Banks provide a convenient and efficient payments system without which specialization in productivity improvement and trade would be greatly impeded. Banks as clearing and settlement institutions constitute channel in the payment system and the medium through which the effects of monetary policies are transmitted to the rest of the economy.

\section{Financial Services Delivery in the Rural Areas of Nigeria}

Rural area is an area that does not well developed, that is to say that the area lack social amenities, good road, pipe bone water, electricity and other social services. In Nigeria, the issue of accessing financial services by the poor and the rural dwellers is a very difficult. Banks have failed to establish their branches in the areas where the poor and rural dwellers should have access to financial services. In most developing countries, the formal financial system reaches to only top 25 per cent of the economically active population. This leaves 75 per cent without access to financial services apart from those provided by money-lenders and family. But the absence of efficiently operating rural financial markets is a serious constraint to sustainable rural development in Nigeria. According to World Bank (2008), the rural space is home to 53 percent of the nation's population and more than 70 percent of its poor. Rural financial access is important for both poverty alleviation and the non-oil growth agenda, a fact recognized by the Nigerian government and its partners.

The poor financial services delivery in the rural are as a result of the following : unfavorable rural operating environment, provision of financial services to rural areas and small-scale entrepreneurs, lack of adequate rural infrastructure, i.e poor availability of electricity, water roads, telephone service, lack of technologies that will enhance financial delivery.

Olaita (2006) observes that the inability of the active poor to obtain credit facility from formal institutions leaves them with no other option than to borrow money from local money-lenders on high interest rates.

Jamil (2008) opines that a large number of active poor in the rural areas is left unattended to by existing microfinance banks. Similarly, Sacerdoti (2005) argued that faster economic growth will not be possible without a deepening of the financial system and, in particular, more support from the banking system. He further showed that there is strong association between access to bank credit and overall economic development of a country. The ability of the poor to borrow a small amount of money to take advantages of a business opportunity not only 
impacts positively on eradication of poverty but also tend to swell the rank of microentrepreneurs (Egwuatu, 2008). Rural financial markets are important because financial intermediation facilitates general economic growth and poverty reduction. Financial intermediaries mobilize funds, allocate them among competing uses, create money, and function as a payments system. The efficient provision of loan, deposit, payment, and insurance services enables entrepreneurship, innovation, and production to develop and flourish. Safe savings facilities, payment services, access to credit, and reliable insurance mechanisms enable poor households to reduce vulnerability by smoothing consumption and mitigating risks. Because rural income cycles are particularly volatile, financial intermediation is especially important to shift purchasing power over time, as well as between net savers and net investors or spenders at any given time.

The availability of appropriately-designed financial services is an essential component of the enabling environment for rural economic growth and poverty reduction. Access to working capital or investment credit offered by rural finance institutions can substantially accelerate the adoption of modern agricultural technologies and production patterns which improve the ability of the rural sector to provide for the subsistence needs of the poor, produce the surplus in primary and intermediary products required for urban consumption and export, and avoid environmental degradation. Suitable credit products can also permit entrepreneurs to take advantage of investment opportunities in processing and off-farm enterprises. The availability of liquid and term deposit services encourages remunerative saving and the accumulation of financial assets, whether for "lumpy" investments and

\section{RESEARCH METHODOLOGY}

The study was carried out in Abia State on some selected Bannks, Small and medium enterprises, active poor in the urban and rural areas of the 17 LGA which were targets for the study.

The study employed primary data that were obtained from questionnaires administered to the 17 Local Government Areas of Abia State and the selected banks meant to serve the dwellers of these areas.

For the primary source, a structured questionnaire was used. 1500 respondents were randomly selected from the total population of 1500 which consist of farmers, retail traders, the owners of rice mill, transporters, cocoa farmers etc. There were two different sets of questionnaires - the first set solicited information from the management and staff of the banks and the second set from the poor in the urban and rural dwellers (Small and medium enterprises) who are the clients of the banks. 1000 questionnaires were returned. The data were analyzed using descriptive statistic -bar chart on the following variables: factors that enhance the banks to exclude SMEs in the financial services and poverty indicators. The study is based on the following objectives (1) To evaluate the factors that enhance the exclusion of small and medium enterprise from financial services (2.) To investigate the level of availability and accessibility of poverty indicators to the poor.

The study was carried out in Abia State where some banks and small and medium enterprise were used as targets for the study. The researcher made use of primary sources to collect data. For the primary source, a structured questionnaire was used. 1000 respondents were randomly selected from the total population of 1500 which include the management staff of the banks and the clients who have benefited from these banks under study. They were initially identified through a preliminary survey. There were two different sets of questionnaires - the first set solicited information from the management staff and the second set from the small and 
medium enterprise. The data were analyzed using descriptive statistics including pyramid. The result in the stacked pyramid above shows that inability of small and medium enterprises to repay, lack of collateral, low income and lack of financial instruments are the major factors that made formal financial institution to exclude SMEs from financial services thus increasing the level of poverty in the country.

Table 1

RESPONSE

Factors that enhance the exclusion of small and medium enterprise from financial services

\begin{tabular}{|l|l|l|}
\hline $\begin{array}{l}\text { Factors that enhance the } \\
\text { exclusion of small and } \\
\text { medium enterprise from } \\
\text { financial services }\end{array}$ & FEESMESFS & $\begin{array}{l}\text { TOTAL } \\
\text { RESPONSE }\end{array}$ \\
\hline Inability to repay & ITR & 950 \\
\hline Low income & LI & 850 \\
\hline Lack of collateral & LOC & 900 \\
\hline Poor sources of fund & PSOF & 600 \\
\hline Lack of financial instrument & LOFI & 800 \\
\hline High cost transaction & HCT & 750 \\
\hline
\end{tabular}

This table indicates the number of people that agreed that these factors enhanced banks to exclude small and medium enterprise (poor).

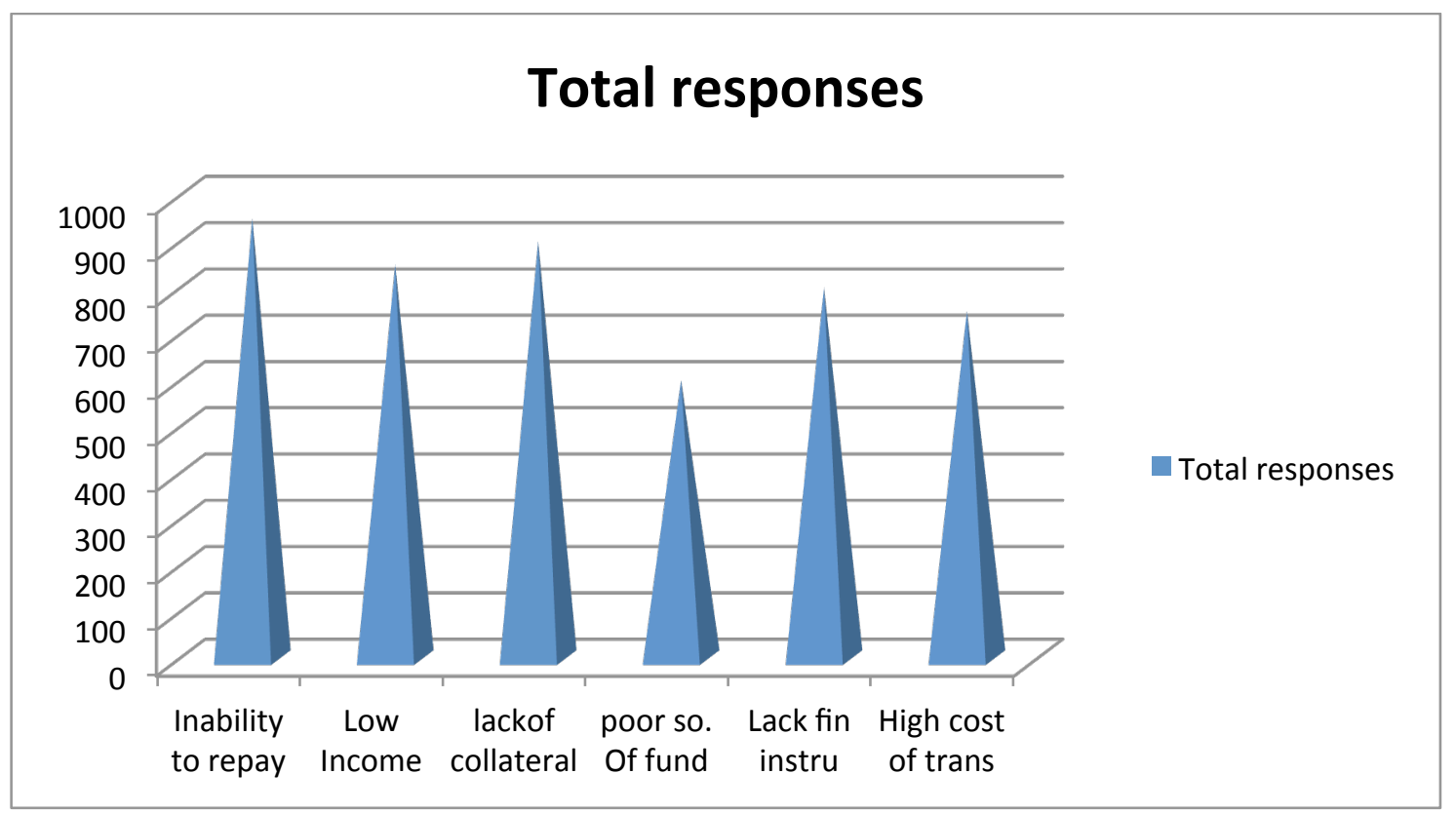

POVERTY INDICATORS TO SMALL AND MEDIUM ENTERPRISE.

The study looked at some components/indicator of poverty:

- Education

- Health 
- House amenities

- Water and sanitation

- Employment

RESPONSES FROM THE 17 LOCAL GOVERNMENT AREAS IN ABIA STATE ON THE LEVEL OF AVAILABILITY AND ACCESSIBILITY OF ALL COMPONENTS OF

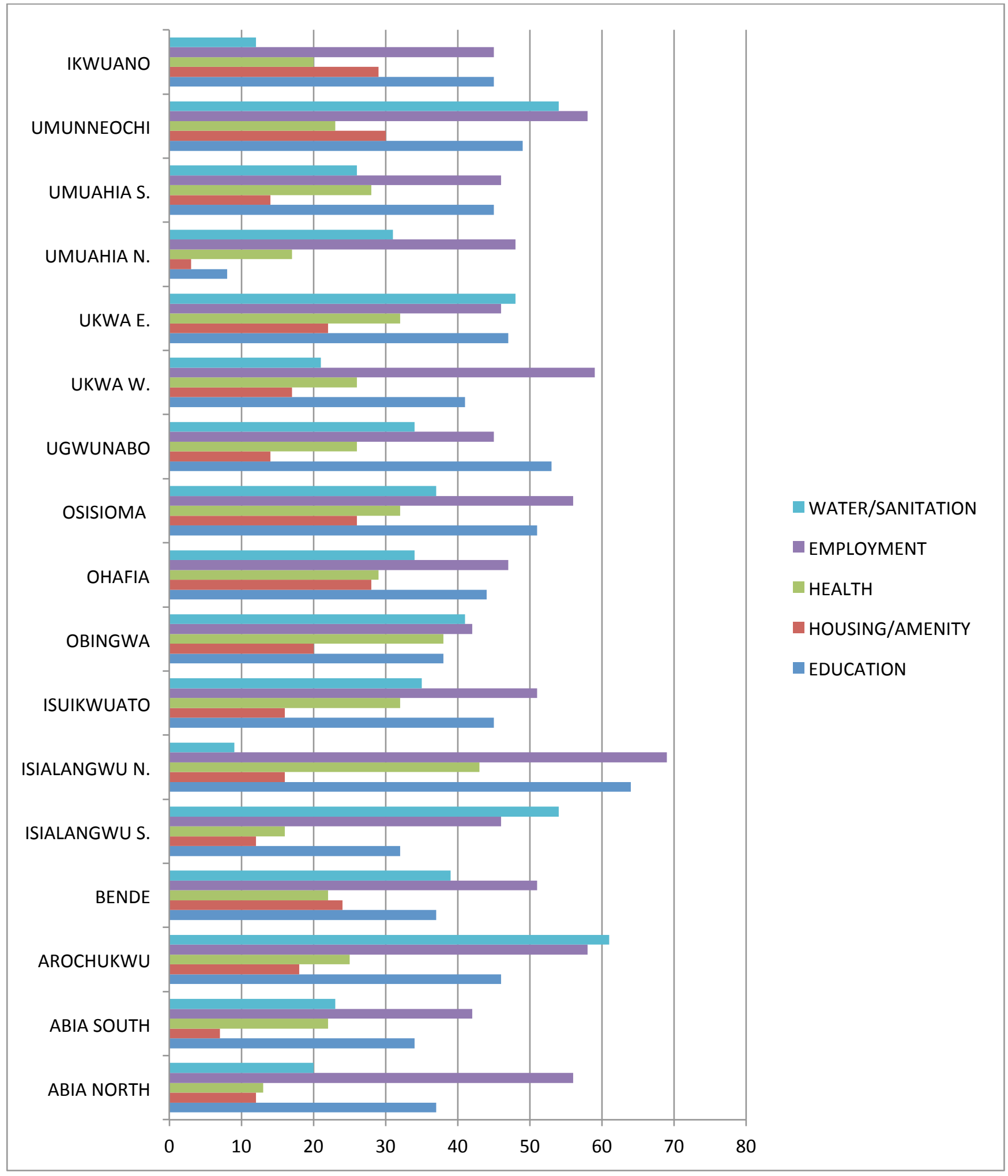




\section{SUMMARY OF THE FINDINGS}

In table 1, the responses obtain from some selected banks and small and medium enterprise shows that the factors that contributed to the exclusion of SMEs from financial services by the commercial banks are: the inability of SMEs to repay loans, lack of collateral to pledge for the loan, low income of SMEs and Lack of sources of funds.

The results from the poverty indicators: Health services, Education, Employment, Housing and household amenities, Water and sanitation indicate that Umunneochi was the most privilege in all the components, meaning that the level of poverty experienced by the people of this L.GA. Is mild compare with other LGAs because of the level of availability of these amenities in this LGA? This is followed by Isialangwa north which is ranked second and Arochukwu was ranked third most privileged LGAs.

However, Obiomangwa and Aba south are seen as the least privileged. The availability and accessibility of the poverty indicators are least available in Obiomangwa and Aba South.

Isuikwuato is seen as the second least (poorest LGAs) in the overall accessibility of these indicators. Obingwa and Ohafia LGAs are the least in having access to these social amenities. The little or non-existence of these social amenities in these area made almost impossible for financial institution to enter and establish their branches. Many people in these rural areas cannot travel far in search of the financial services. Small businesses owners, especially peasant farmers who produce various crops cannot find market for it, because of lack of the required social amenities.

\section{CONCLUSIONS AND RECOMMENDATION}

The paper stressed the need to develop viable and responsive financial services for the poor in Nigeria which will contribute toward improved savings and investments in the country.

The paper conclude that accessibility of financial services by the poor will go a long way to improve their living conditions, make them self reliance and enhance economic development.

Number of poor people in the rural areas make money and keep the money under their pillows due to lack of financial services in the areas. The money which could have contributed to the growth of the volume of savings in the country is under the pillows as idle cash-yielding no interest.

We recommend that Central Bank of Nigeria should improve in their monitor duty to enhance the effective performance of the banking sectors in the rural area of the country.

Government should provide infrastructure in the rural and sub urban areas of the country for the expansion of branches in the rural areas. The presence of infrastructure will attract other providers of funds even from outside the country. This will also enable banks to intensify the use of mobile banking in the rural areas and encourage the role of sourcing funds from the surplus units and supply to the deficit units of the economy by the banks. Financial institutions should accommodate the active poor ones in their financial services. Government should therefore help to give people the tools they need to work their way out of poverty by providing avenue for small loans, business training and other financial services to poor men and women to start their own businesses. 


\section{References}

Abiodun F, (2010) "Small and Medium Scale Enterprises in Nigeria: The Problems and Prospects". PhD student in University of Ibadan, Ibadan Nigeria.

Collins, D., J. Morduch, S. Rutherford and O. Ruthven (2009) Portfolios of the Poor: How the World's Poor live on \$2 a Day. Princeton, NJ: Princeton University Press.

Cornaggia, J. (2008). “Does Access to External Finance Improve Productivity? Evidence from a Natural Experiment".Paper Presented at International Seminar Held at Baylor University, USA.

Egwuatu, B. S. C. (2008). "Reducing poverty through better credit delivery: The Asian experience”. Central Bank of Nigeria Bullion, 32(1), 8-16.

Ehigiamusoe, G. (2008). "The role of microfinance institutions in the economic development of Nigeria". Central Bank of Nigeria Bullion, 32(1), 17-24.

Kanu. C. (2014). Financial (In) Justice: Interrogating factors that affect performance of Microfinance Banks in Nigeria.

Jamil B (2008) "Microfinance as a tool for poverty alleviation in Nigeria" Paper Presented at Sensitization Work shop on Microfinance Banking in Kano State

Molokwu B. (2005), Challenges of Small and Medium Enterprises in Nigeria. Conference paper

Nobes C., Parker R. (2004). Comparative International Accounting, Prentice Hall, 2004.

Nasir, J. (2002): “Poverty Alleviation and Sustainable Development in Nigeria”, Daily Trust

Odoko, F. O. (2008). Beyond finance: Strategies for poverty reduction in Nigeria. Central Bank of Nigeria Bullion,

$31(1), 35-36$.

Ojeka, Stephen A. and Dr. O. Mukoro Dickson (2011) International Financial Reporting Standard and SMEs in Nigeria: Perceptions of Academic International Journal of Research in Commerce \& Management vol. 2.

Olaitan, M. A. (2001). Emerging issues on micro and rural financing in Nigeria. Central Bank of Nigeria Bullion 25(1), 6471.

Sacerdot, E. (2005). Access to Bank Credit in Sub-Saharan Africa: Key Issues and Reform Strategies. IMF Working Paper, WP/05/166. Pp3-22.

Todaro, M.P. (2000) Economic Development. Seventh Ed. Addison Wesley Longman, Inc...

United Nation Development Programme (1990). Human Development Report. Oxford University Press, London.

Programme Support Document, 19th February (2010). 6th Country Programme: Poverty Reduction Support Programme of the Government of Nigeria, 2003-2007. Draft

Adeyemi, K. S., 2008, Institutional Reforms for Efficient Microfinance Operations in Nigeria. Central Bank of Nigeria.

Bullion, 32(1), 26-34

Central Bank of Nigeria (2005). Annual Reports and Statement of Accounts.

Jamil B (2008) "Microfinance as a tool for poverty alleviation in Nigeria" Paper Presented at Sensitization Workshop on Microfinance Banking in Kano State

Nasir, J. (2002): “Poverty Alleviation and Sustainable Development in \Nigeria”, Daily Trust

Nasr, S. (2006). Access to Finance and Economic Growth in Egypt. The World Bank. Washington D.C. . .

Odoko, F. O., 2008, beyond finance: Strategies for poverty reduction in Nigeria. Central Bank of Nigeria Bullion, Okpara, G.C., 2010, microfinance banks and poverty alleviation in Nigeria Journal of Sustainable Development in Africa (Volume 12 , No.6, 2010)

Olaitan, M. A., 2006, Finance for Small and Medium Enterprises: Nigeria's Agricultural Credit Guarantee Scheme Fund. Journal of Farm Management, 3(2), 1-9. 
Clementina, K., \& Egwu, C. O. K. (2015). Financial Exclusion of Small and Medium Enterprise and Poverty Alleviation: Nigeria Experience. Archives of Business Research, 3(4), 63-77.

Sacerdot, E., 2005, Access to Bank Credit in Sub-Saharan Africa: Key Issues and Reform Strategies. IMF Working Paper, WP/05/166.

Yunus, M. (2006). A Hands Up, Not a Hand out: Why not Microfinance for Katrina Victims? The Wall Street Journal. 


\section{APPENDIX}

INDEXES FOR POVERTY

NAMES OF LGAS

EDUCATION

HEALTH

EMPLOYMENT

WATER \& SANITATION

HOUSE

AMENITIES

ABA NORTH

ABA SOUTH

AROCHUKWU

BENDE

IKWUANO

ISIALA NGWA

NORTH

ISIALA NGWA SOUTH

ISUIKWUATO

OBINGWA

OHAFIA

OSISIOMA

UGWUNABO

UKWA EAST

UKWA WEST

UMUAHIA NORTH

UMUAHIA SOUH

UMUNNEOCHI

4

3

11

12

8

2

17

8

5

16

15

6

12

1

8

6

14

1
5
8
5
4

12

10

14

1

3

5

17

12

15

1

10

15

8

2

3

16

5

9

5

5

14

3

3

2 